\title{
CIPROFLOXACIN RESISTANCE AMONG CLINICAL ISOLATES FROM ACUTE RESPIRATORY INFECTIONS PATIENTS AT COMMUNITY HEALTH CENTERS IN TASIKMALAYA, INDONESIA
}

\author{
DANNI RAMDHANI ${ }^{1 *}$, SRI AGUNG FITRI KUSUMA ${ }^{1}$, RESMI MUSTARICHIE ${ }^{1}$, ELIN FEBRIANA ${ }^{1}$, DEDE SEDIANA ${ }^{2}$, \\ MOKHAMAD AFIFI ${ }^{1}$
}

${ }^{1}$ Department of Pharmaceutical Analysis and Medicinal Chemistry, Faculty of Pharmacy, Universitas Padjadjaran, Indonesia. ${ }^{2}$ Tasikmalaya City Health Office, Pharmacy Section, Indonesia. Email: ramdhani07@gmail.com

Received: 1 November 2016, Revised and Accepted: 24 January 2017

ABSTRACT

Objective: Acute respiratory infections (ARIs) are acute infections of any part of the respiratory tract and related structures including middle ear, paranasal sinuses, and pleural cavity. This study was to determine the resistance in isolates of the pathogen of the patients with ARIs in clinics in Tasikmalaya against antibiotic ciprofloxacin and effectiveness of this antibiotic.

Methods: Isolates were obtained from swabs cavity of 332 patients with ARIs. Ciprofloxacin resistance against pathogenic isolates of diseased patients ARIs was determined using paper disk diffusion method.

Results: The patient isolates shows that it is resistance to the antibiotic ciprofloxacin with the percentage of $19.81 \%$.

Conclusion: Ciprofloxacin level of antibiotic resistance being mediated resistance. Routine surveillance and education to health professionals and patients are very important to overcome the problem.

Keywords: Acute respiratory infections, Antibiotic resistance, Ciprofloxacin, Clinical isolates.

(c) 2017 The Authors. Published by Innovare Academic Sciences Pvt Ltd. This is an open access article under the CC BY license (http://creativecommons. org/licenses/by/4. 0/) DOI: http://dx.doi.org/10.22159/ajpcr.2017.v10s2.19484

\section{INTRODUCTION}

Acute respiratory infections (ARIs) are a leading cause of morbidity and mortality of infectious diseases in the world. Nearly, four million people worldwide die each year due to respiratory infection. The mortality is very high in infants, children, and elderly people, especially in countries with low per capita income and middle [1].

Antibiotic usage resistance rates vary from one country to another [2]. It is observed that countries with the highest per capita antibiotic consumption have the highest resistance rates. It is not only the amount of antibiotic used that select for resistance but also the number of individuals receiving the drug and the population density also matters [3].

In Tasikmalaya, Indonesia, the main causes of infant and child mortality are respiratory infections. In this case, pneumonia is the disease that needs the main priority to control in health development in Tasikmalaya, West Java [4].

ARIs are the main target therapies to overcome bacterial infections because the etiology of respiratory bacteria and viruses that cause infection are the second most frequent causes of respiratory infection $[5,6]$.

Antibiotics are used to treat the infection. One of the antibiotics that used for the treatment of ARIs is ciprofloxacin. Ciprofloxacin has a broad spectrum of activity and is active against many organisms that are resistant to penicillin, cephalosporins, and aminoglycosides [7]. Initially, ciprofloxacin has been successfully used to treat infections caused by Gram-negative and Gram-positive organisms and resistance case was rare [8].

Reduced susceptibility to fluoroquinolones has become a major problem, mostly in Asia $[9,10]$. There are several reports which alert on the customary dispensing of fluoroquinolone of the pathogenic bacteria [11]. Currently, antibiotic therapy is often misused as a result of irrational use and ease of people to obtain antibiotics without a prescription. It triggers the high multidrug resistance [2]. The use of antibiotics repeatedly and improperly is the main ones as over the counter drugs, which may lead to increased resistance cause of the increase in the number of bacteria that are resistant to antibiotics [12].

\section{MATERIALS AND METHODS}

Tools

The tools used in this study is the autoclave (Hirayama), volume micropipette 5-1000 mL (Eppendorf), tip micropipette, incubator (Sakura IF-4), laminar air flow, calipers, burners spritus, ose, sterile cotton bud, and glassware tools.

Materials

Materials used in this study consisted of antibiotic, bacterial testing, and bacterial growth media.

\section{Test materials}

Materials tested were ciprofloxacin from PT. Bernofarm used in community health center in Tasikmalaya, West Java, Indonesia. McFarland standard No. 0.5 (Merck, USA), and physiological saline $0.9 \%$.

\section{Bacteria test}

Test bacteria used are pathogenic isolates from swabs cavity patients at the community health center Taman Sari, Cibeureum Tasikmalaya, West Java.

\section{Bacterial growth media}

Bacteria growth medium used was Mueller Hinton Agar (MHA) (Merck) with a concentration of $43 \mathrm{~g} / \mathrm{l}$ and Mueller Hinton Broth (Oxid, Basingstoke, UK) at a concentration of $21 \mathrm{~g} / \mathrm{l}$, MHA (Merck, USA) with a concentration of $43 \mathrm{~g} / \mathrm{l}$. 


\section{Method}

\section{Sample size}

The study population is drawn from a patient who has been diagnosed by a doctor at the health center. The ARIs patients are patients who seek treatment at community health center in Taman Sari and Cibeureum, Tasikmalaya, Indonesia, with a period from March to June 2015.

1. Criteria for inclusion are the patients who were diagnosed with ARI by doctors at community health centers, Taman Sari and Cibereum from March to June 2015.

2. Exclusion criteria that patients with other complications.

The sample size in this study was obtained using the following formula:

$$
\mathrm{N}=\frac{(\mathrm{Z} \alpha)^{2} \cdot P \cdot \mathrm{Q}}{\mathrm{d}^{2}}
$$

Notes:

$\mathrm{N}$ : Sample size

$\mathrm{Z} \alpha$ : Standard deviation

P: Proportion category $=0.5$

Q: $1-\mathrm{P}=0.5$

D: Precision $=0.06$

The use of precision numbers 0.06 aims for the closeness with which results of replicate analyses of a sample agree.

In this study, the desired confidence level of $95 \%$ so that the value of $\alpha$ is $5 \%$ and the $\mathrm{Z}$ is 1.96 while the acceptable error (value d) by $6 \%$. Thus, the required sample size (N) is 266 samples. In this study, the sample size used was 332 it aims to obtain more accurate data so that the research results will be better.

\section{Inoculation of pathogens}

Patients are first examined by a doctor at the health center, after a positive diagnosis of patients suffering from disorders ARIs then directed to a laboratory to take a swab of the oral cavity upper portion.

Inoculation is done after the patient's oral swabs were incubated for $18-24 \mathrm{hrs}$ at $37^{\circ} \mathrm{C}$ by taking a swab using a sterile loop and streaked onto agar slant. Incubate back at $37^{\circ} \mathrm{C}$ for $18-24 \mathrm{hrs}$.

\section{Isolation technique pathogens}

Isolation of bacteria is done in stages as follows:

a. Making test medium.

A total of $19 \mathrm{~g}$ of Mueller-Hinton order was dissolved in $500 \mathrm{ml}$ of distilled water and then sterilized using an autoclave at a temperature of $121^{\circ} \mathrm{C}$ for 15 minutes. The medium can be stored at $4^{\circ} \mathrm{C}$.

b. Isolation of bacteria.

Pathogenic bacterial isolates from the patient's mouth to be inoculated pathogenic bacteria were isolated by scraping the use ose upward growth media MHA. Bacterial isolates of the pathogen would be isolated to form a color, the structure of the colony, as well as the morphology of the same.

\section{Testing pathogen resistance isolates from oral swabs}

Testing of antibiotic resistance through several stages:

a. Sample preparation

Ciprofloxacin dosage equivalent to $100 \mathrm{mg}$ were weighed and added to distilled water until dissolved and then added to a buffer solution of D3 up to $100 \mathrm{ml}$. Further dilution to reach a concentration of $5 \mu \mathrm{g} / \mathrm{ml}$. D3 solution was prepared by as much as $16.73 \mathrm{~g}$ potassium phosphate dibasic and $0.523 \mathrm{~g}$ of potassium phosphate monobasic dissolved in $1 \mathrm{l}$ of distilled water. $\mathrm{pH}$ was adjusted to $8.0 \pm 0.1$ with phosphoric acid or potassium hydroxide $18 \mathrm{~N} 10 \mathrm{~N}$.

b. Resistance test

Methods for determining the diameter of inhibition zone are the agar diffusion method with paper discs techniques. The inhibition diameter is measured using a caliper formed as a parameter for determining the resistance of bacteria to antibiotic tested.

\section{RESULTS AND DISCUSSION}

\section{Sample test results}

The number of samples obtained swabs from ARI patients from clinics are 332 samples can be seen in Table 1 .

Both the number of samples that can be used to test the resistance and identification totaled 308, while the number of defective samples totaling 24. The sample is a sample which is damaged during the incubation period there is no bacterial growth. This can be caused by several factors such as errors in sampling as clinics officers no cotton buds moistened with sterile distilled water in advance, or cotton buds are not on the surface of the patient's oral cavity and the sample damaged by temperatures that are too hot at the time of transport.

Samples isolate patients with ARIs taken from Clinics in Tasikmalaya using test tubes to be skewed. Before isolation using test tubes for oblique and resistance tests, all equipment must be sterilized in advance to avoid microorganisms that could interfere with the results of testing. To test tube slant that has been sent to the clinics in Tasikmalaya then used a sterile swab tool to take sputum isolates of patients with ARIs and streaked onto agar slant that has been provided. After that, the oblique order was brought to the Laboratory of Microbiology, Faculty of Pharmacy, University of Padjadjaran and directly incubated in an incubator. The samples were incubated at $37^{\circ} \mathrm{C}$ for $18-24 \mathrm{hrs}$ and then removed and tested resistance to ciprofloxacin.

\section{Resistance test results}

Test of resistance to ciprofloxacin performed using paper disc method. The paper disc method chosen because this method is more simple and have high accuracy. In addition, this method can also save processing time because the samples used in large numbers. In addition, the paper disc method can also save processing time because the samples used in large numbers. Paper disc method is also more accurate because it uses a fixed concentration in the paper discs which reduce errors while doing resistance tests.

Results of the test of resistance can be observed by inhibition zone is formed. The inhibition zone is a clear area formed around the paper disk which indicated that bacteria cannot grow around the paper disc area. This test is intended to determine whether antibiotics are still sensitive to the test bacterium. Inhibition zone accepted as a guide in determining if something is still effective drugs used can be seen in Table 2.

Samples of bacteria from the oral cavity of patients tested was dissolved in physiological saline so that the color is muddy, bacteria in the solution of $\mathrm{NaCl}$ is compared to $0.5 \mathrm{McFarland}$ turbidity. After that, $20 \mathrm{ml}$ of bacteria in a solution of $\mathrm{NaCl}$ is taken using a micropipette is inserted into a sterile petri dish that contains $20 \mathrm{ml}$ MHA. Bacteria in the solution

Table 1: Research samples

\begin{tabular}{|c|c|c|c|}
\hline Source of samples & $\begin{array}{l}\text { Fine } \\
\text { samples }\end{array}$ & $\begin{array}{l}\text { Damaged } \\
\text { samples }\end{array}$ & Description \\
\hline Taman Sari Clinic & 63 & 9 & \multirow{3}{*}{$\begin{array}{l}\text { Damaged } \\
\text { samples=no } \\
\text { growth of bacteria }\end{array}$} \\
\hline Cibeureum Clinic & 245 & 15 & \\
\hline Samples total amount & 308 & 24 & \\
\hline
\end{tabular}

Table 2: Inhibition zone of standard antibiotics [3]

\begin{tabular}{lllll}
\hline Antibiotic & $\begin{array}{l}\text { Concentration } \\
\text { in paper } \\
\text { disc }(\boldsymbol{\mu g})\end{array}$ & $\begin{array}{l}\text { Resistant } \\
\text { inhibition } \\
\text { zone } \\
(\mathbf{m m})\end{array}$ & $\begin{array}{l}\text { Intermediate } \\
\text { zonhe }(\mathbf{m m})\end{array}$ & $\begin{array}{l}\text { Sensitive } \\
\text { inhibition } \\
\text { zone } \\
(\mathbf{m m})\end{array}$ \\
\hline Ciprofloxacin & 5 & $<19$ & $17-21$ & $\geq 22$ \\
\hline
\end{tabular}


of $\mathrm{NaCl}$ which has been incorporated into the entire portion is flattened so that in a petri dish using a spreader so average. Put each paper disc that contains the antibiotic as much as $20 \mu \mathrm{l}$ using a micropipette.

The paper disc is inserted into an agar medium in a petri dish using tweezers under aseptic state to each of the allotted portion. After incubated for $18-24 \mathrm{hrs}$ at $37^{\circ} \mathrm{C}$ in the incubation chamber. After that the observed inhibition zone diameter is formed on the surface so that in a petri dish that has been incubated. Inhibitory zone diameters were measured using calipers, and the value of inhibition zone was noted. Antibiotics used are antibiotic used in Clinics in Tasikmalaya for ARIs patients that this study can be seen from antibiotics which are still effective for use in Clinics in Tasikmalaya. Antibiotic used to be reconstituted and diluted by a predetermined dose. The number of samples that are resistant to ciprofloxacin can be seen in Table 3.

The test results of resistance that can be seen in Table 3 show that as many as 308 samples from clinical isolates were tested; the samples that are resistant to ciprofloxacin are 61 samples.

Using stratified random sampling (SRS) technique, the sample was divided into two stratum based on clinics which were chosen as the source of the isolates. To determine the proportion percentage of the resistance in Tasikmalaya, the researcher used proportion valuation techniques. Estimation for the proportion also involves massive proportions for each stratum. Therefore, through an SRS of size N, estimation for the proportion is:

$$
\mathrm{P}_{\mathrm{st}}=\sum_{\mathrm{i}=1}^{\mathrm{L}}\left(\frac{\mathrm{Ni}}{\mathrm{N}}\right) \mathrm{Pi}
$$

With

$$
\mathrm{Pi}=1 / \mathrm{n} \sum_{\mathrm{j}=1}^{\mathrm{ni}} \mathrm{X}_{\mathrm{ij}}
$$

$\mathrm{X}_{\mathrm{ij}}=1$ if the sampling unit has the characteristics (resistant)

$\mathrm{X}_{\mathrm{ij}}=0$ if the sampling unit does not have the characteristic (sensitive).

Based on the data obtained, researcher can determine the proportion as follows:

$$
\mathrm{P}_{\mathrm{St}}=\left(\frac{63}{308} \times \frac{1}{63} \times 13\right)+\left(\frac{245}{308} \times \frac{1}{245} \times 48\right)
$$

\section{$=0.1981$ from 1}

With 95\% level of confidence, the percentage of resistance to the antibiotic ciprofloxacin in Tasikmalaya is $19.81 \%$.

There are several factors that can cause bacterial resistance to antibiotics, including changes in the structure of the bacteria so that the bacteria have modified themselves; it can produce enzymes that can inactivate drugs [13]. Another factor that can affect antibiotic resistance is the misuse of antibiotics in which the drug is administered though the indications are not clear. In addition, this is due to repeated use of antibiotics and patients not adhering to the appropriate dose of antibiotic use. [12].

Many studies have shown that educational/training interventions, whether conducted in large or small groups, can successfully improve

Table 3: Resistance test result

\begin{tabular}{lll}
\hline Sample & Ciprofloxacin & \\
\cline { 2 - 3 } & Resistant & Sensitive \\
\hline Taman Sari Clinic & 13 & 50 \\
Cibeureum Clinic & 48 & 197 \\
Total & 61 & 247 \\
\hline
\end{tabular}

targeted antibiotic prescribing patterns by an average of $20 \%$ or more if they are well designed [14].

The effectiveness of peer education is enhanced when the message is delivered or endorsed by local opinion leaders and made relevant to the doctor's own practice $[15,16]$. Providing feedback to clinicians regarding their own antibiotic prescribing practices has been a successful technique for achieving behavior change [16]. Feedback entails comparisons with peers or with a standard or indicator [17].

Several factors favor the development of bacterial resistance to antibiotics in developing countries:

1. Less potent activity: Some of the antibiotics provided in developing countries have decreased potency because of degradation or adulteration of the drug, or because of the presence of a lower concentration of active substances $[7,18,19]$.

2. Lack of diagnostic laboratories: Most of the hospitals in developing countries do not have clinical microbiology laboratories to perform routine analyses for microbiological diagnosis.

3. Over-the-counter availability: In most developing countries, antibiotics can be purchased without a prescription in pharmacies, general stores, markets, and from street hawkers [11].

\section{CONCLUSION}

From this study, it can be concluded that there has been resistance in pathogenic isolates from the oral swab of ARIs patients at community health center of Taman Sari and Cibereum Tasikmalaya, West Java, Indonesia to the antibiotic ciprofloxacin as much as $19.81 \%$.

\section{ACKNOWLEDGMENTS}

The authors are deeply grateful to the subjects participating in this study. The author would like to thank Tasikmalaya City Health Office and the doctors at a community health center in Cibereum and Taman Sari, Tasikmalaya. The author also thanked Mokhamad Afifi for its cooperation in this study.

\section{REFERENCES}

1. WHO. Bacterial etiology of serious infections in young infants in developing countries: Results of a multicenter study. WHO Young Infants Study Group. Pediatr Infect Dis J 1999;18 10 Suppl: S17-22.

2. Refdanita R, Maksum R, Nurgani A, Endang P. Faktor Yang Mempengaruhi Ketidaksesuaian Pengunaan Antibiotika dengan Uji Kepekaan di Ruang Intensif Rumah Sakit Fatmawati Jakarta Tahun 2001 - 2002. Vol. 8. Makara: Kesehatan; 2004. p. 21-6.

3. Clinical and Laboratory Standards Institute. Performance Standards for Antimicrobial Susceptibility Testing; Tweny-First Informational Supplement. CLSI document M 100-S 21 (ISBN 1-56238-742-1). Wayne, PA, USA: Clinical and Laboratory Standards Institute; 2011.

4. Profil Dinas Kesehatan Profinsi Jawa Barat. Pola Penyakit Penderita Rawat Jalan di Clinics Umur 1-4 Tahun; 2012. Available from: http://www.depkes.go.id/resources/download/12_Profil_Kes.Prov. JawaBarat 2012.pdf.

5. Anne M. Upper Respiratory Tract Infection: Treatment and Medication; 2007. Available from: http://www.emedicine.medscape.com/article/ 302460-overview.

6. WHO. Antibiotic resistance: Synthesis of recommendation by expert policy groups. Alliance for the Prudent Use of Antibiotics. Geneva: WHO; 2001.

7. McGregor A. Counterfeit drugs flood developing world. Lancet 1997;350:1690.

8. Bazile-Pham-Khac S, Truong QC, Lafont JP, Gutmann L, Zhou XY, Osman M, et al. Resistance to fluoroquinolones in Escherichia coli isolated from poultry. Antimicrob Agents Chemother 1996;40(6):1504-7.

9. Brown JC, Shanahan PM, Jesudason MV, Thomson CJ, Amyes SG. Mutations responsible for reduced susceptibility to 4-quinolones in clinical isolates of multi-resistant Salmonella typhi in India. J Antimicrob Chemother 1996;37(5):891-900.

10. Sørensen TL, Monnet D. Control of antibiotic use in the community: The Danish experience. Infect Control Hosp Epidemiol 2000;21(6):387-9.

11. Lansang MA, Lucas-Aquino R, Tupasi TE, Mina VS, Salazar LS, Juban N, et al. Purchase of antibiotics without prescription in Manila, 
the Philippines. Inappropriate choices and doses. J Clin Epidemiol 1990;43(1):61-7.

12. WHO. Bacterial Resistance; 2011. Available from: http://www.ino. searo.who.int/linkfiles/home_whd11-messages-11_03_31-faqs.pdf.

13. Waller DG, Renwick AG, Hillier K. Medical Pharmacology and Therapeutics. Edinburgh: Harcourt Publishers Limited; 2001.

14. Interventions and Strategies to Improve the Use of Antimicrobials in Developing Countries, WHO/CDS/CSR/DRS/2001.9,16. Available from: http://www.whqlibdoc.who.int/hq/2001/WHO_CDS_CSR DRS2001.9.pdf.
15. Schaffner W, Ray WA, Federspiel CF, Miller WO. Improving antibiotic prescribing in office practice. A controlled trial of three educational methods. JAMA 1983;250(13):1728-32.

16. Schoenbaum SC. Feedback of clinical performance information. HMO Pract 1993;7(1):5-11.

17. Belongia EA, Schwartz B. Strategies for promoting judicious use of antibiotics by doctors and patients. BMJ 1998;317(7159):668-71.

18. Land T. Combating counterfeit drugs. Nature 1992;355(6357):192.

19. Pécoul B, Chirac P, Trouiller P, Pinel J. Access to essential drugs in poor countries: A lost battle? JAMA 1999;281(4):361-7. 